\title{
SLC2A2 wt Allele
}

National Cancer Institute

\section{Source}

National Cancer Institute. SLC2A2 wt Allele. NCI Thesaurus. Code C119008.

Human SLC2A2 wild-type allele is located within 3q26.2-q27 and is approximately $31 \mathrm{~kb}$ in length. This allele, which encodes solute carrier family 2 , facilitated glucose transporter member 2 protein, is involved in glucose transport. 